\title{
Risk factors for post-weaning diarrhoea on piglet producing farms in
} Finland

\author{
Taina M Laine*1, Tapani Lyytikäinen², Maija Yliaho ${ }^{3}$ and Marjukka Anttila ${ }^{4}$
}

Address: ${ }^{1}$ Finnish Food Safety Authority Evira, Production Animal Health Unit, Mustialankatu 3, FI-00790 Helsinki, Finland, ${ }^{2}$ Finnish Food Safety Authority Evira, Risk Assessment Unit, Mustialankatu 3, FI-00790 Helsinki, Finland, ${ }^{3}$ Rural Advisory Centre of Southern Ostrobothnia, Huhtalantie 2, FI-60220 Seinäjoki, Finland and ${ }^{4}$ Finnish Food Safety Authority Evira, Pathology Unit, Mustialankatu 3, FI-00790 Helsinki, Finland

Email: Taina M Laine* - taina.laine@evira.fi; Tapani Lyytikäinen - tapani.lyytikainen@evira.fi; Maija Yliaho - maija.yliaho@proagria.fi; Marjukka Anttila - marjukka.anttila@evira.fi

* Corresponding author

Published: 18 June 2008

Acta Veterinaria Scandinavica 2008, 50:2I doi:10.1 I86/I75I-0|47-50-2I

Received: 3 December 2007

Accepted: 18 June 2008

This article is available from: http://www.actavetscand.com/content/50/I/2I

(c) 2008 Laine et al; licensee BioMed Central Ltd.

This is an Open Access article distributed under the terms of the Creative Commons Attribution License (http://creativecommons.org/licenses/by/2.0), which permits unrestricted use, distribution, and reproduction in any medium, provided the original work is properly cited.

\begin{abstract}
Background: Post-weaning diarrhoea (PWD) is a significant gastrointestinal disease in pigs. It is considered a multifactorial disease associated with proliferation of enterotoxigenic Escherichia coli in the intestinal tract of affected pigs. The aim of this study was to analyse risk factors related to the occurrence of PWD on Finnish piglet producing farms.
\end{abstract}

Methods: The data of a follow-up study of 73 conventional piglet producing farms was used in the case-control study. The selection of the 4I PWD case and 28 control farms was based on the use of antimicrobials for treating diarrhoea in weaned pigs and the answers related to the occurrence of diarrhoea after weaning in the questionnaire. Four intermediate farms were excluded from the statistical analysis.

Altogether 39 factors related to herd characteristics, weaner pig management and pig health were studied. The median number of sows was $59.0(\mathrm{IQR}=44.0 ; 74.5)$ and $52.5(\mathrm{IQR}=36.8 ; 61.5)$ on the case and the control farms, respectively.

The significances of the univariable associations between the explanatory variables and the outcome variable were tested, and in the multivariate analysis quasibinomial generalized linear models were applied.

Results: An increased risk of PWD was associated with the regimen of twice a day feeding and feed restriction after weaning $(P=0.02$; compared to feeding three or more meals a day or the use of ad libitum feeding) and with a higher number of sows on the farm $(P=0.02$; risk increasing with increasing number of sows). Automatic temperature control was associated with a decreased risk of PWD ( $P=0.03$; compared to manual temperature control).

Conclusion: Twice a day feeding of newly-weaned pigs should be avoided if the amount of feed given is restricted. Variation in ambient temperature should be minimized in housing of newlyweaned pigs and this can be achieved by using automatic temperature control. With increasing number of sows in the herds the risk of PWD increases and more attention should be paid to prevention of post-weaning diarrhoea. 


\section{Background}

Antimicrobial resistance in pathogenic bacteria is a global threat and therefore increasing attention is being paid to the prudent use of antibiotics in food-producing animals [1]. Gastrointestinal diseases of growing pigs are economically important for pig production worldwide [2] and enteric bacterial infections are often treated with antimicrobials. Detailed data registered in 2004 by the VetStat programme on antimicrobial use in Denmark showed that prescriptions for weaner pigs accounted for more than one third of the total antimicrobial consumption in pigs and that gastrointestinal diseases were the most common indications for prescriptions in this age group [3].

PWD is considered to be a multifactorial disease $[4,5]$.

Recently weaned pigs are variously predisposed to enteric disorders. Newly weaned pigs are stressed by nutritional, psychological, environmental and physiological factors [4]. At weaning the feed is changed from milk to a weaner diet, piglets are separated from their sow and often moved from the farrowing pen and mixed with unfamiliar pigs. Weaned pigs also lose passive intestinal immunity provided by antibodies in sow's milk [6]. After weaning there are alterations in the structure [7] and function $[8,9]$ of the piglet small intestine, changes in intestinal $E$. coli flora of piglets $[10,11]$ and impairment of immune functions in early-weaned piglets $[12,13]$.

During the first two weeks after weaning, pathogenic Escherichia coli plays a significant role in the etiology of PWD $[5,14,15]$, although infection with pathogenic E. coli does not unequivocally lead to the development of diarrhoea in weaned pigs [5,16-18].

Pens contaminated with pathogenic E. coli strains are likely sources of infection for weaned pigs, but the infection can also be acquired before weaning [19].

On farms outbreaks of PWD can occur suddenly and during outbreaks the morbidity may be over $50 \%$ among weaned piglets $[14,15]$. Severely affected pigs can die acutely $[14,20]$. In surviving pigs diarrhoea can be transient [5] or it can last for up to four days [20]. The case fatality rate seldom exceeds $10 \%$ in uncomplicated cases [21].

PWD associated with enterotoxigenic E. coli typically affects pigs during the immediate post-weaning period. In contrast to PWD, the enteric diseases caused by Lawsonia intracellularis and Brachyspira - bacteria also affect growers and fattening pigs $[22,23]$.

Several factors have been reported to influence the occurrence of diarrhoea in weaned pigs. The susceptibility for diarrhoea after weaning has been associated with management related factors such as low feed intake during the first week after weaning [24], excessive feed intake [16], low number of meals [25], the hygiene and management level [24], low weaning weight and age [26,27], moderate cold stress [17], draught [28], texture of feed [29], number of feeder spaces per pen [29] and vaccinating gestating sows against PRRS (porcine reproductive and respiratory syndrome) [29]. Cleaning pens between batches of weaned pigs has been associated with a decreased risk of PWD [30].

In Finland the use of antimicrobial growth promoters (AGPs) was voluntarily stopped soon after the use of olaquindox and carbadox was banned in the European Union in 1999. Until the ban these two substances had been added to commercial weaner feeds also in Finland.

In piglet production without AGPs knowledge of the relationship between management related factors and occurrence of diarrhoea in weaned pigs is important. Management related measures can be used in prevention of PWD [4] and finding specific solutions for each farm has been emphasized [31].

This study was done to provide information on risk factors related to the occurrence of PWD on Finnish piglet producing farms after the AGP withdrawal.

\section{Methods}

\section{Study sample}

The farms were recruited among herds that used a production-data recording system run by the Association of the Rural Advisory Centres. A total of 260 piglet producing farms were supervised by these centers in 1999. Animal production advisors of the Rural Advisory Centres provided the farms located in four different provinces. Random sampling was not possible, because all the farms that were willing to participate were needed. In the beginning the herds had either few or moderate problems with postweaning diarrhoea based on the evaluation of the farmer. It was not possible to select the case and the control farms directly because before the study began, there was no comprehensive knowledge about the occurrence of postweaning diarrhoea on Finnish piglet-producing farms.

Our case-control study is based on the material of the follow-up study of 73 conventional piglet producing farms in 1999-2000 in which data related both to the occurrence of diarrhoea and to antimicrobial treatments for diarrhoea after weaning were collected. The total followup period was either 16 months (33 farms) or 12 months (40 farms) and it was divided into consecutive 4-month periods [32]. 
The follow-up data were used to assign the case and the control farms related to the occurrence of PWD. A total of 41 farms were defined as PWD cases and 28 farms as control farms. Four farms were classified being intermediate relative to occurrence of PWD and these farms were excluded from the statistical analysis.

Two types of herds were included in the case-control study: 41 farrowing herds and 28 farrow-to-finish herds. A farrowing herd only raises piglets to the mean body weight of about $25 \mathrm{~kg}$ and after that feeder pigs are delivered to specialised finishing herds. Farrow-to-finish herds raise their own finishing pigs.

Concerning the health status of the farms, Finland is considered free of classical swine fever, swine vesicular disease, Aujeszky's disease and transmissible gastroenteritis (TGE) and porcine reproductive and respiratory syndrome (PRRS) has not been reported in Finland [33].

\section{Data collection}

The follow-up data were used both for the definition of the PWD cases and the control farms and for obtaining data on explanatory variables.

The data on the occurrence of PWD were collected with help of the questionnaire and from records the farmers had kept on cases of diarrhoea after weaning and antimicrobial treatments related to them. The questionnaire included separate closed questions both about the occurrence of diarrhoea in pigs within 14 days after weaning and diarrhoea over 14 days after weaning. The farmers were asked to answer these questions based on their experiences during a few previous months. The given alternatives were: no cases, seldom/occasionally, periodically and regularly. During the follow-up in a 4-month period the use of antimicrobials for treatment of diarrhoea after weaning was calculated as the number of piglets treated divided by the number of piglets weaned.

Data on explanatory variables were obtained from the production-data recording system (number of sows, the average age at weaning, piglets weaned/sow/year) and from the questionnaire (farm management related to weaning of piglets; the environment of weaned pigs; health status related to Mycoplasma hyopneumoniae and Sarcoptes scabiei; sow vaccination, observations concerning health of weaned pigs). The questionnaire consisted of 53 questions, and mainly closed questions were used. The data of one questionnaire per farm was used in the analysis. During the follow-up study animal production advisors visited the farms three times and every time a similar questionnaire was filled. These advisors of seven different Rural Advisory Centres and one slaughter-house co-operative also normally visited the farms and collected data for production monitoring run by the Association of the Rural Advisory Centres. A total of 33, 27, 6 and 3 questionnaires were responded in March-May, June-August, September-November and December-February, respectively. For the case herds the questionnaire was used that was responded during a time when most severe problems with PWD were experienced according to the follow-up data. The classification of the farms was done retrospectively and at the time of the farm visits the advisors were not aware of the herd status (as case or control). Eight advisors accounted for 61 questionnaires filled on both PWD case and control farms and four advisors accounted each a questionnaire on either 1-3 case or control farms.

\section{Definition of outcome variable}

The unit of observation was the farm. Based on the retrospective follow-up data the farms were divided into control farms that experienced few problems related to postweaning diarrhoea and PWD case farms that had moderate to severe problems related to post-weaning diarrhoea. The outcome variable was thus dichotomous.

On the 28 control farms the questionnaire was responded in a 4-month follow-up period during which these farms had treated less or no more than $5 \%$ of weaned piglets with antimicrobials for diarrhoea. In addition, these farms gave answers 'no cases' or 'seldom/occasionally' in the questionnaire related to the occurrence of diarrhoea after weaning.

The definition of the PWD case farms was based on antimicrobial treatments for diarrhoea and experienced problems related to PWD. The two alternative criteria were: 1 ) The questionnaire was responded in a 4-month follow-up period (or just after it) during which the farm treated at least $10 \%$ or more of the weaned piglets with antimicrobials for diarrhoea after weaning (34 cases) or 2) In the questionnaire the farm responded 'periodically' or 'regularly' to the questions related to the occurrence of diarrhoea after weaning ( 7 cases).

Four farms with intermediate data on antimicrobial use for diarrhoea after weaning (6-9\%) in the 4-month periods of the questionnaires and with answers 'seldom/occasionally' related to the occurrence of diarrhoea after weaning were excluded from the statistical analysis.

\section{Definition of the explanatory variables}

Tables 1 and 2 list the variables under study. Due to the evident synergism and/or collinearity three combined variables were generated. Feeding regimen was divided into two categories by combining restricted feeding after weaning and providing feed only twice a day to newly-weaned pigs to be one category (F-R2M) and other feeding regimens (ad libitum feeding, at least three meals per day with 
Table I: Continuous explanatory variables on 4 I post-weaning diarrhoea case farms and 28 control farms. IQR, Interquartile range.

\begin{tabular}{|c|c|c|c|c|c|}
\hline & \multicolumn{2}{|c|}{ PWD cases } & \multicolumn{2}{|c|}{ Controls } & \multirow[t]{2}{*}{$\mathbf{P}$} \\
\hline & Median & IQR & Median & IQR & \\
\hline Age at weaning & 33.0 & $30.5 ; 36.0$ & 34.5 & $30.0 ; 36.8$ & 0.47 \\
\hline Environmental temperature for the weaners & 21 & $20 ; 23$ & 22 & $20 ; 23$ & 0.69 \\
\hline Temperature in the lying area for the weaners & 24 & $22 ; 26$ & 24 & $22 ; 27$ & 0.99 \\
\hline Number of sows & 59.0 & $44.0 ; 74.5$ & 52.5 & $36.8 ; 61.5$ & 0.07 \\
\hline Piglets weaned/sow/year & 18.9 & $17.4 ; 20.9$ & 18.5 & $17.5 ; 20.5$ & 0.98 \\
\hline
\end{tabular}

or without feed restriction) to be the other (F-OTHER). The two other combined explanatory variables generated as indices are shown in Table 3.

\section{Statistical analysis}

Cross tabulation and chi-square test or Fisher's exact test were used to test the significance of the univariable associations between the explanatory variables and the outcome variable. Fisher's exact test was used when expected cell frequencies were $<5$. The likelihood ratio chi-square test probability for a variable to be included in the multivariable analysis was set to be less than 0.20 . The same probability limit was used for explanatory variables tested with Fisher's exact test. In the preliminary step in the selection of the variables the bilateral relationships between possible explanatory variables were checked to be able to lower the risk of multicollinearitity [34]. For variables evidencing a strong structural collinearity or having a statistically significant connection (e.g. totally slatted floor and use of bedding) only the variable most strongly associated with the outcome was selected.

Finally, use of bedding, feeding regimen (F-R2M), automatic temperature control in the accommodation of the weaners, a feeder as an only feed supply in the weaning pen and the average number of sows on the farm were offered to the model. The number of sows was applied as a covariate because it appeared to influence to the probability of having more problems with diarrhoea in weaned piglets. In addition, generated indices (Table 3) were included in this further analysis one at a time. In the multivariate analysis the influence of explanatory variables to the risk of experiencing problems related to post-weaning diarrhoea in piglets was studied by applying quasibinomial generalized linear models $[35,36]$. Calculations were done on R (2.51) [37] statistical programme, using GLM procedure, which applies iterative reweighted least squares as an estimation method [36].

All the coefficients were estimated at the average sow number of the data by centering the covariate. Significances of individual parameters were tested by multiple Wald test where the model without one of the explanatory variables was compared against the full model.

\section{Results \\ Farms}

The typical point of time for the occurrence of diarrhoea in pigs within 14 days after weaning is shown in Table 4.

In older weaned pigs (after the first two weeks post weaning) no cases of diarrhoea had occurred on 11 control farms (39\%) and on 11 PWD case farms (27\%). Three PWD case farms $(7 \%)$ suffered periodically from diarrhoea over 14 days after weaning. On all the other farms cases of diarrhoea over 14 days after weaning had occurred seldom/occasionally.

No cases of oedema disease was observed in weaned pigs on 24 control farms $(86 \%)$ and on 30 PWD case farms (73\%) during the previous months. The rest of the farms had had cases of oedema disease seldom/occasionally.

Two case farms added zinc to weaner feed.

The median group size for pigs at about $25 \mathrm{~kg}$ bodyweight was $12(\mathrm{IQR}=10 ; 20)$ and $10(\mathrm{IQR}=10 ; 15)$ on the case farms and the control farms, respectively.

Most of the farms were free from Mycoplasma hyopneumoniae infection and Sarcoptes scabiei infestation (Table 2).

\section{Results of the statistical analysis}

Both generated indices (HYGIND and MANIND) failed to give a statistical connection with the probability of experiencing problems related to post weaning diarrhoea $(P=$ 0.86 for HYGIND; $P=0.40$ for MANIND). Also the use of bedding appeared to have no statistically significant $(P=$ 0.23 ) influence on the probability of experiencing problems with post-weaning diarrhoea.

The feeding regimen with feed restriction and two meals a day after weaning (F-R2M) and a higher number of sows on the farm were both associated with an increased risk of PWD. On the contrary, the presence of automatic temper- 
Table 2: Non-continuous explanatory variables on $4 \mathrm{I}$ post-weaning diarrhoea case farms and 28 control farms.

\begin{tabular}{|c|c|c|c|c|}
\hline \multirow[t]{2}{*}{ Explanatory variable } & \multirow[t]{2}{*}{ Categories } & \multicolumn{2}{|c|}{ Number (\%) of herds } & \multirow[t]{2}{*}{$P$-value } \\
\hline & & Cases & Controls & \\
\hline \multicolumn{5}{|l|}{ Herd } \\
\hline \multirow[t]{3}{*}{ Type of herd } & & & & 0.75 \\
\hline & Farrowing herd & $25(61.0)$ & $16(57.1)$ & \\
\hline & Farrow-to-finish herd & $16(39.0)$ & $12(42.9)$ & \\
\hline \multirow[t]{4}{*}{ The number of sows increased by $50 \%$ or more from 1998 to 2000} & & & & $0.58^{e}$ \\
\hline & Yes & $16(39.0)$ & $12(42.9)$ & \\
\hline & No & $23(56.1)$ & $13(46.4)$ & \\
\hline & No data on 1998 & $2(4.9)$ & $3(10.7)$ & \\
\hline \multicolumn{5}{|l|}{ Pen and environment } \\
\hline \multirow[t]{4}{*}{ Floor type in the farrowing pens } & & & & $\mathrm{NE}^{\mathrm{c}}$ \\
\hline & Solid & $28(68.3)$ & $21(75.0)$ & \\
\hline & Partly slatted & $9(22.0)$ & $7(25.0)$ & \\
\hline & Fully slatted & $4(9.7)$ & 0 & \\
\hline \multirow[t]{5}{*}{ Floor type in the nursery pens } & & & & $0.23^{c}$ \\
\hline & Solid & $14(34.2)$ & II (39.3) & \\
\hline & Partly slatted & $20(48.8)$ & $16(57.1)$ & \\
\hline & Fully slatted & $6(14.6)$ & I (3.6) & \\
\hline & Deep bedding & I (2.4) & 0 & \\
\hline \multirow[t]{3}{*}{ Use of bedding for newly-weaned pigs } & & & & 0.06 \\
\hline & Yes & $30(73.2)$ & $26(92.9)$ & \\
\hline & No & II (26.8) & $2(7.1)$ & \\
\hline \multirow{3}{*}{ Heating in the accomodation for weaners } & & & & 1.00 \\
\hline & Yes & $39(95.1)$ & $27(96.4)$ & \\
\hline & No & $2(4.9)$ & I (3.6) & \\
\hline \multirow[t]{3}{*}{ Temperature control } & & & & 0.12 \\
\hline & Automatic & $17(4 \mid .5)$ & $17(60.7)$ & \\
\hline & Manual & $24(58.5)$ & II (39.3) & \\
\hline \multirow[t]{3}{*}{ Heated lying area for weaners } & & & & 0.40 \\
\hline & Yes & $37(90.2)$ & $27(96.4)$ & \\
\hline & No & $4(9.8)$ & I (3.6) & \\
\hline \multicolumn{5}{|l|}{ Animal husbandry and hygiene } \\
\hline \multirow[t]{3}{*}{ Piglets moved from the farrowing pen within 7 days after weaning } & & & & 0.95 \\
\hline & Yes & $12(29.3)$ & $8(28.6)$ & \\
\hline & No & $29(70.7)$ & $20(7 \mathrm{I} .4)$ & \\
\hline \multirow[t]{3}{*}{ Mixing of litters after weaning } & & & & 0.43 \\
\hline & Yes & $30(73.2)$ & $18(64.3)$ & \\
\hline & $\mathrm{No}^{\mathrm{a}}$ & II (26.8) & $10(35.7)$ & \\
\hline \multirow[t]{3}{*}{ Runts moved to groups of younger weaned piglets } & & & & 0.48 \\
\hline & Yes & $17(4 \mid .5)$ & $14(50.0)$ & \\
\hline & No & $24(58.5)$ & $14(50.0)$ & \\
\hline Piglets moved within 7 days after weaning to a separate room with own & & & & 0.85 \\
\hline & Yes & $8(19.5)$ & $6(21.4)$ & \\
\hline & No & $33(80.5)$ & $22(78.6)$ & \\
\hline Reared in a room with own airspace for weaners and growers from I-3 & & & & 0.60 \\
\hline & Yes & $15(36.6)$ & $12(42.9)$ & \\
\hline & No & $26(63.4)$ & $16(57.1)$ & \\
\hline HYGIND (see Table 3) & & & & 0.86 \\
\hline & $0-0.5$ & $8(19.5)$ & $5(17.9)$ & \\
\hline & $1-1.5$ & $8(19.5)$ & $7(25.0)$ & \\
\hline & $2-2.5$ & $9(22.0)$ & $6(21.4)$ & \\
\hline & $3-3.5$ & II (26.8) & $5(17.9)$ & \\
\hline & $4-4.5$ & $2(4.9)$ & $2(7.1)$ & \\
\hline & $5-6$ & $3(7.3)$ & $3(10.7)$ & \\
\hline Feeding and watering & & & & \\
\hline Creep feeding & & & & NE \\
\hline
\end{tabular}


Table 2: Non-continuous explanatory variables on $4 \mathrm{I}$ post-weaning diarrhoea case farms and 28 control farms. (Continued)

\begin{tabular}{|c|c|c|c|c|}
\hline & Yes & $40(97.6)$ & $28(100.0)$ & \\
\hline & No & I (2.4) & 0 & \\
\hline \multirow[t]{3}{*}{ Commercial feed for weaners } & & & & NE \\
\hline & Yes & $4 \mid(100.0)$ & $26(92.9)$ & \\
\hline & No & 0 & $2(7.1)$ & \\
\hline \multirow[t]{4}{*}{ Piglet age at change from unmixed weaner feed to other feed } & & & & $0.79 f$ \\
\hline & 6-7 weeks & $28(68.3)$ & $19(67.9)$ & \\
\hline & 8 weeks or older & $12(29.3)$ & $7(25.0)$ & \\
\hline & No data or own feed & I (2.4) & $2(7.1)$ & \\
\hline \multirow[t]{3}{*}{ A feeder as an only feed supply in the pen for newly-weaned piglets } & & & & 0.18 \\
\hline & Yes & $15(36.6)$ & $6(21.4)$ & \\
\hline & No & $26(63.4)$ & $22(78.6)$ & \\
\hline \multirow[t]{3}{*}{ Through feeding for newly-weaned piglets } & & & & 0.20 \\
\hline & Yes & $20(48.8)$ & $18(64.3)$ & \\
\hline & No & $21(51.2)$ & $10(35.7)$ & \\
\hline \multirow[t]{4}{*}{ Through feeding for older weaned pigs } & & & & $0.44 \mathrm{e}$ \\
\hline & Yes & $25(61.0)$ & $20(7 \mid .4)$ & \\
\hline & No & $15(36.6)$ & $8(28.6)$ & \\
\hline & No data & I (2.4) & & \\
\hline \multirow[t]{3}{*}{ Floor feeding } & & & & 0.85 \\
\hline & Yes & $8(19.5)$ & $6(21.4)$ & \\
\hline & No & $33(80.5)$ & $22(78.6)$ & \\
\hline \multirow[t]{3}{*}{ Feed provided for newly weaned pigs per day (times) } & & & & 0.20 \\
\hline & Two times & $2 I(5 I .2)$ & $10(35.7)$ & \\
\hline & At least 3 times or ad lib & $20(48.8)$ & $18(64.3)$ & \\
\hline \multirow[t]{5}{*}{ Special measures related to feeding after weaning } & & & & $0.53^{d}$ \\
\hline & Restricted feeding & $14(34.2)$ & $12(42.9)$ & \\
\hline & Restricted feeding and other ${ }^{b}$ & $18(43.9)$ & $8(28.6)$ & \\
\hline & Otherb & $6(14.6)$ & I (3.6) & \\
\hline & None & $3(7.3)$ & $7(25.0)$ & \\
\hline \multirow{3}{*}{$\begin{array}{l}\text { Restricted feeding and feed given twice a day for newly-weaned piglets (F- } \\
\text { R2M) }\end{array}$} & & & & 0.17 \\
\hline & Yes & $20(48.8)$ & $9(32.1)$ & \\
\hline & No & $21(51.2)$ & 19 (67.9) & \\
\hline \multirow[t]{3}{*}{ Separate water supply for piglets in the farrowing pen (nipple or cup) } & & & & NE \\
\hline & Yes & $4 \mid(100.0)$ & $27(96.4)$ & \\
\hline & No & 0 & I (3.6) & \\
\hline \multirow[t]{3}{*}{ Type of water supply in the nursery pen } & & & & NE \\
\hline & Nipple & $39(95.1)$ & $28(100.0)$ & \\
\hline & Cup or other & $2(4.9)$ & 0 & \\
\hline \multicolumn{5}{|l|}{ Farmer observations } \\
\hline \multirow[t]{4}{*}{ Seasonal variation in the occurrence of PWD } & & & & $0.97 \mathrm{e}$ \\
\hline & Yes & $15(36.6)$ & $10(35.7)$ & \\
\hline & No & $26(63.4)$ & $17(60.7)$ & \\
\hline & No data & & I (3.6) & \\
\hline \multirow[t]{4}{*}{ Variation in the occurrence of PWD between pens } & & & & $0.70^{e}$ \\
\hline & Yes & $4(9.8)$ & $4(14.3)$ & \\
\hline & No & $37(90.2)$ & $22(78.6)$ & \\
\hline & No data & & $2(7.1)$ & \\
\hline \multirow[t]{3}{*}{ Lying behaviour of the weaners observed by the farmer } & & & & NE \\
\hline & Yes & $40(97.6)$ & $28(100.0)$ & \\
\hline & No & I (2.4) & 0 & \\
\hline \multicolumn{5}{|l|}{ Health } \\
\hline Behavioural vices occurring often in weaned piglets & Yes & $2(4.9)$ & 0 & NE \\
\hline & No & $39(95.1)$ & $28(100.0)$ & \\
\hline Problems with pre-weaning diarrhoea & & & & 0.51 \\
\hline & Yes & $7(17.1)$ & $3(10.7)$ & \\
\hline & No & $34(82.9)$ & $25(89.3)$ & \\
\hline Sow vaccination against $E$. coli & & & & $0.95 \mathrm{e}$ \\
\hline & Yes & $24(58.5)$ & $16(57.1)$ & \\
\hline & No & $17(41.5)$ & $11(39.3)$ & \\
\hline & No data & & I (3.6) & \\
\hline Mycoplasma hyopneumoniae status & & & & 1.00 \\
\hline
\end{tabular}


Table 2: Non-continuous explanatory variables on $4 \mathrm{I}$ post-weaning diarrhoea case farms and 28 control farms. (Continued)

\begin{tabular}{|c|c|c|c|c|}
\hline \multirow{7}{*}{ Sarcoptes scabiei status } & M. hyo + & $4(9.8)$ & $2(7.1)$ & \multirow{7}{*}{1.00} \\
\hline & M. hyo - & $36(87.8)$ & 25 (89.3) & \\
\hline & Not known & I (2.4) & I (3.6) & \\
\hline & & & & \\
\hline & S. scab + or medication & $3(7.3)$ & $3(10.7)$ & \\
\hline & S. scab - & $36(87.8)$ & $25(89.3)$ & \\
\hline & Not known & $2(4.9)$ & 0 & \\
\hline
\end{tabular}

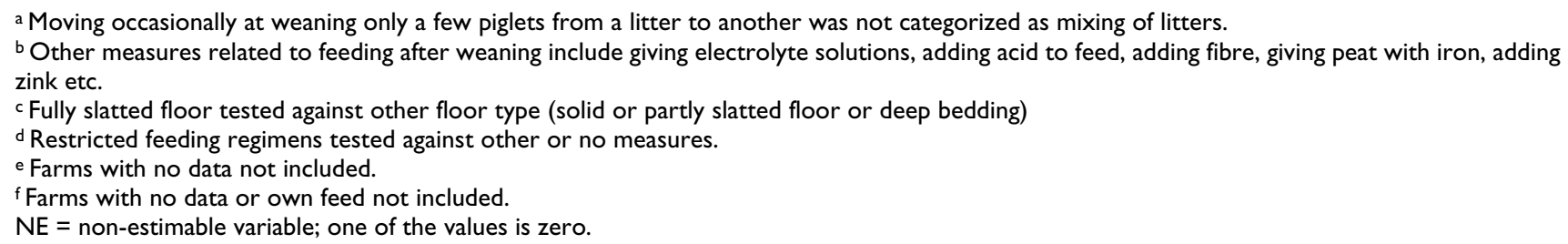

ature control in the accommodation of weaners seemed to be related to a decreased risk of PWD (Table 5). The 95\% confidence interval of the odds ratio for the feeding regimen (F-R2M) was 1.19-19.12 and for the automatic temperature control in the accommodation of weaners it was $0.08-0.93$.

The presence of a feeder as an only feed supply in the weaning pen was included in the model because it improved the estimates of the other explanatory variables although it was not statistically significant $(P=0.08)$ in the multivariate analysis. Dispersion parameter for quasibinomial family was estimated to be 1.11. Null deviance of the model was $93.19(\mathrm{df}=68)$ and residual deviance was $76.34(\mathrm{df}=64)$.

Expected value of probability of experiencing moderate or severe problems related to post weaning diarrhoea can thus be described by:

$$
\mathrm{P}=\frac{\mathrm{e}^{0.115+1.564 \mathrm{~F}-1.306 \mathrm{~A}+0.032(\mathrm{NS}-60)+1.277 \mathrm{FPW}}}{1+\mathrm{e}^{0.115+1.564 \mathrm{~F}-1.306 \mathrm{~A}+0.032(\mathrm{NS}-60)+1.277 \mathrm{FPW}}}
$$

where $\mathrm{F}$ is the feeding regimen $(1=$ two meals and feed restriction after weaning; $0=$ other feeding regimens), $\mathrm{A}$ is the use of automatically regulated heating in the accommodation of weaners ( $1=$ yes; $0=$ no), NS is the number of sows on the farm and FPW is the use of a feeder as an only feed supply for newly-weaned pigs ( $1=$ yes; $0=$ no).

\section{Discussion}

The feeding regimen after weaning, the presence of automatic temperature control in the accomodation for weaners and the number of sows on the farm had an effect on the occurrence of problems related to PWD.

The cases and the controls are considered representative based on the recognition of PWD, the herd size and the production level. Follow-up data was used to assign the case farms and the control farms related to the occurrence of post-weaning diarrhoea (PWD). PWD is a common enteric disorder of pigs and also well recognised by the farmers. In diagnostic samples sent to our laboratory from the farms participating in the follow-up, pathogenic Escherichia coli was a common finding in samples from piglets weaned during the previous fortnight [32]. The average herd size of the study farms was nearly the same as the average herd size on Finnish piglet producing farms taking part in a production monitoring system in 2000 [38]. Also according to the parameter of number of weaned pigs/sow/year the study farms were comparable to the farms taking part in the production-data recording system run by the Association of Rural Advisory Centres in 2000.

The risk of PWD was higher on the farms that fed the weaned piglets only twice a day with restricted amount of feed than on the farms that provided more than two meals per day with or without feed restriction or gave feed ad libitum after weaning. Our result related to the feeding regimen is in accordance with earlier results concerning the number of meals per day. With the amount of feed being similar, an increase in the number of meals per day has produced less severe signs of diarrhoea [25]. At this phase the weaned pigs can also be encouraged to eat more by increasing the number of meals per day or giving feed freely [39]. It is a common phenomenon in the immediate post-weaning period that pigs eat less than the optimum amount of feed [40] and it has been shown that at a farm level low feed intake after weaning is a risk factor for diarrhoea in weaners [24].

Despite the possible detrimental effects of low feed intake, restrictive feeding after weaning has been used as a preventive measure against PWD. In our study feed restriction as such in the immediate post-weaning period was not associated with PWD in the univariable analysis. In earlier studies overeating after weaning has been con- 
Table 3: Combined variables related to hygienic measures, empty time of the pens and age segregation after weaning.

\begin{tabular}{|c|c|c|}
\hline Title and definitions & Score & Scale \\
\hline HYGIND & & $0-6$ \\
\hline Farrowing pens & & $0-3$ \\
\hline Washed after every litter or after every two litters & 1 & \\
\hline Disinfection after the pens have been washed & I & \\
\hline Washed occasionally (e.g. few times a year) & 0 & \\
\hline Disinfection occasionally or use of dry disinfectant & 0 & \\
\hline Empty time $\geq 4$ days & I & \\
\hline Empty time $\mathrm{I}-3$ days & 0.5 & \\
\hline Empty time $<$ I day & 0 & \\
\hline Nursery pens & & $0-3$ \\
\hline Washed after every group or after every two groups & 1 & \\
\hline Disinfection after the nursery pens have been washed & I & \\
\hline Nursery pens washed occasionally (e.g. few times a year) & 0 & \\
\hline Disinfection occasionally or use of dry disinfectant & 0 & \\
\hline Deep bedding in the nursery pen & 1 & \\
\hline Empty time $\geq 4$ days & 1 & \\
\hline Empty time $\mathrm{I}-3$ days & 0.5 & \\
\hline Empty time $<$ I day & 0 & \\
\hline MANIND = HYGIND + scores related to age segregation & & $0-8$ \\
\hline Age segregation & & $0-2$ \\
\hline
\end{tabular}

First week after weaning

Weaners moved within 7 days after weaning to a room (with own airspace) intended for weaners only or for weaners and growers up to about $25 \mathrm{~kg}$ bodyweight

From I-3 weeks after weaning up to about the body weight of $25 \mathrm{~kg}$

Weaners reared in a room (with own airspace) intended only for weaners and growers

nected with the occurrence of PWD [16] and restriction of feed intake has reduced the incidence of and severity of post-weaning diarrhoea in early-weaned pigs $[17,25,41,42]$ and in pigs weaned at the age of 5 weeks [43]. However, under farm circumstances restricted feeding can also predispose to diarrhoea. One explanation is that weaned pigs with a low feed intake may eat the excreta of their penmates and be exposed to a high number of faecal micro-organisms which then predisposes the pigs to infectious diarrhoea [31].

Automatic temperature control in the accommodation of weaners reduced the risk of PWD. Wide seasonal and diurnal variations in the temperature are typical for the cli- mate in Finland [44] and therefore requirements on the temperature regulation capacity are high. A stable and optimal ambient temperature is very important during the two first weeks after weaning [45]. Temperature fluctuations have been associated with a greater incidence of post-weaning diarrhoea [46]. Skirrow [27] reported that large temperature fluctuations did not increase the risk of PWD, however, it is likely that ambient temperatures on Australian farms stay quite near to the optimum for weaned pigs despite an inadequate temperature control.

An increase in herd size was associated with a higher risk of post-weaning diarrhoea despite that our case and control farms were small compared with some other studies 
Table 4: The typical point of time for the occurrence of diarrhoea within 14 days after weaning on the farms. The control farms had had either no cases of diarrhoea or cases of diarrhoea seldom/occasionally.

\begin{tabular}{lcc}
\hline Period for diarrhoea occurrence & Farms & Controls (\%) \\
\hline & PWD cases (\%) & $\mathbf{n}=\mathbf{2 8}$ \\
\hline No cases of diarrhoea & $\mathbf{n}$ & $5(17.9)$ \\
Cases of diarrhoea (also if few) & $0(0)$ & $1(3.6)$ \\
0-4 days after weaning & $5(12.2)$ & $16(57.1)$ \\
5-10 days after weaning & $33(80.5)$ & $0(0)$ \\
0-10 days after weaning & $2(4.9)$ & $2(7.1)$ \\
II-14 days after weaning & $1(2.4)$ & $4(14.3)$ \\
Typical time period not given & $0(0)$ & \\
\hline
\end{tabular}

Table 5: The parameter estimates of the final generalized linear model describing the probability of a farm having post-weaning diarrhoea.

\begin{tabular}{|c|c|c|c|c|}
\hline Variable & Estimate $^{d}$ & LCLd $95 \%$ & UCLd $95 \%$ & $\boldsymbol{P}$ \\
\hline Intercept & 0.115 & -0.992 & 1.222 & $0.84^{a}$ \\
\hline $\begin{array}{l}\text { Feeding regimen: Feed restriction with two meals a day (F-R2M) vs. Three or more } \\
\text { meals a day with or without feed restriction or ad libitum feeding (F-OTHER) }\end{array}$ & 1.564 & 0.176 & 2.951 & $0.02^{\mathrm{b}}$ \\
\hline Temperature control: Automatic vs. Manual & -1.306 & $-2.54 I$ & -0.072 & $0.03^{b}$ \\
\hline Number of sows ${ }^{c}$ & 0.0321 & $5.50 \times 10^{-4}$ & 0.064 & $0.02^{\mathrm{b}}$ \\
\hline A feeder as an only feed supply in a pen after weaning: Yes/No & 1.277 & -0.217 & $|5.98|$ & $0.08^{b}$ \\
\hline
\end{tabular}

$\mathrm{LCL}=$ Lower confidence limit $\mathrm{UCL}=$ Upper confidence limit

a Significance estimated by t-test

b Significance estimated by multiple Wald test

c Number of sows is corrected to the average sow number in the data $(n=60)$.

dValues are given in $\log _{\mathrm{e}}$-scale.

concerning herd size and enteric disease [26,47]. Our result is in contrast to a Danish study [26] in which risk of post-weaning diarrhoea decreased with increasing herd size. Production volumes and herd sizes vary between countries and according to the classification of the Danish study [26] most farms in our study would have been in the category of the smallest farms. In the Danish study it was thought that measures to decrease the risk of introducing infections when purchasing breeding stock and the management were better in bigger herds [26].

Factors such as hygiene [24,30], feed [15,30,48,49] and feed supplements [49-52] have been reported to affect the occurrence of PWD. In our study all farms except for two used commercial weaner feeds and therefore the type of feed could not be included in the analysis.

Due to the multifactorial etiology, finding case-specific preventive measures against PWD is a challenging task. Further studies are needed concerning different types of production systems to identify more predisposing factors and to define complex interactions between the factors relevant to PWD occurrence at a herd level. Our results should be regarded indicative for those factors that were found to increase the risk for PWD.

\section{Conclusion}

Twice a day feeding of newly-weaned pigs should be avoided if the amount of feed given is restricted. After weaning the piglets should be fed at least three times a day or feed should be given ad libitum. Variation in ambient temperature should be minimized in housing of newlyweaned pigs and this can be achieved by using automatic temperature control. With increasing number of sows in the herds the risk of PWD increases and more attention should be paid to prevention of post-weaning diarrhoea.

\section{Abbreviations}

AGPs: Antimicrobial growth promoters; PWD: Post-weaning diarrhoea

\section{Competing interests}

The authors declare that they have no competing interests. 


\section{Authors' contributions}

TML has been involved in the initial design of the study and has been the main responsible for data analysis and drafting the manuscript, TL performed the statistical analysis and participated in the writing the manuscript, MY did most of the arrangements related to recruitment of the farmers and data acquisition and participated in the design of the questionnaires, MA was involved in the initial design and cooperation of the study and contributed to the writing of the manuscript. All authors have read and approved the final manuscript.

\section{Acknowledgements}

The co-operation of the farmers is greatly appreciated. We also thank Ms. Sari Kaukonen for technical assistance. We gratefully acknowledge the financial support from the Ministry of Agriculture and Forestry, Finland, and a grant by the Finnish Veterinary Foundation.

\section{References}

I. World Health Organisation: WHO Global Strategy for Containment of Antimicrobial Resistance. WHO/CDS/CSR/DRS/ 200 I.2 Original:English. 200I:I-96 [http://www.who.int/drugre sistance/WHO Global Strategy English.pdf].

2. Thomson JR: Diseases of the digestive system. In Diseases of swine Edited by: Straw BE, Zimmermann JJ, D'Allaire S, Taylor DJ. Ames, lowa: Blackwell Publishing; 2006:37-55.

3. Anonymous: DANMAP 2004 - Use of antimicrobial agents and occurrence of antimicrobial resistance in bacteria from food animals, foods and humans in Denmark. Statens Serum Institut; Danish Veterinary and Food Administration; Danish Medicines Agency; Danish Institute for Food and Veterinary Research; 2005: I-95.

4. Hampson DJ: Postweaning Escherichia coli Diarrhoea in Pigs. In Escherichia coli in domestic animals and humans Edited by: Gyles CL. Wallinford, UK: CAB International; 1994:I7I-I9I.

5. Madec F, Bridoux N, Bounaix S, Cariolet R, Duval-Iflah Y, Hampson DJ, et al.: Experimental models of porcine post-weaning colibacillosis and their relationship to post-weaning diarrhoea and digestive disorders as encountered in the field. Vet Microbiol 2000, 72:295-310.

6. Porter P, Noakes DE, Allen WD: Secretory IgA and Antibodies to Escherichia coli in Porcine Colostrum and Milk and their Significance in the Alimentary Tract of the Young Pig. Immunology 1970, 18:245-257.

7. Hampson DJ: Alterations in piglet small intestinal structure at weaning. Res Vet Sci 1986, 40:32-40.

8. Kidder DE, Manners MJ: The level of distribution of carbohydrases in the small intestine mucosa of pigs from 3 weeks of age to maturity. $\mathrm{Br} J$ Nutr 1980, 43:141-153.

9. Hampson DJ, Kidder DE: Influence of creep feeding and weaning on brush border enzyme activities in the piglet small intestine. Res Vet Sci 1986, 40:24-31.

10. Melin L, Jensen-Waern M, Johannisson A, Ederoth M, Katouli M, Wallgren P: Development of selected faecal microfloras and of phagocytic and killing capacity of neutrophils in young pigs. Vet Microbiol 1997, 54:287-300.

II. Katouli M, Melin L, Jensen-Waern M, Wallgren P, Mollby R: The effect of zinc oxide supplementation on the stability of the intestinal flora with special reference to composition of coliforms in weaned pigs. J Appl Microbiol 1999, 87:564-573.

12. Blecha F, Pollmann DS, Nichols DA: Weaning pigs at an early age decreases cellular immunity. J Anim Sci 1983, 56:396-400.

13. Wattrang E, Wallgren P, Lindberg A, Fossum C: Signs of infections and reduced immune functions at weaning of conventionally reared and specific pathogen free pigs. Zentralbl Vet med B 1998, 45(I):7-17.

14. Svendsen J, Larsen JL, Bille N: Outbreaks of post weaning Escherichia coli Diarrhoea in Pigs. Nord Vet Med 1974, 26:314-322.
I5. Tzipori S, Chandler D, Smith M, Makin T, Hennessy D: Factors contributing to postweaning diarrhoea in a large intensive piggery. Aust Vet J 1980, 56:274-278.

16. Hampson DJ, Smith WC: Influence of creep feeding and dietary intake after weaning on malabsorption and occurrence of diarrhoea in the newly weaned pig. Res Vet Sci 1986, 41:63-69.

17. Wathes CM, Miller BG, Bourne FJ: Cold stress and post-weaning diarrhoea in piglets inoculated orally or by aerosol. Anim Prod 1989, 49:483-496.

18. Melin L, Katouli M, Lindberg A, Fossum C, Wallgren P: Weaning of piglets. Effects of an exposure to a pathogenic strain of Escherichia coli. J Vet Med B Infect Dis Vet Public Health 2000, 47:663-675

19. Hampson DJ, Fu ZF, Robertson ID: Investigation of the source of haemolytic Escherichia coli infecting weaned pigs. Epidemiol Infect 1987, 99:I49-153.

20. Sarmiento Jl, Casey TA, Moon HW: Postweaning diarrhea in swine: experimental model of enterotoxigenic Escherichia coli infection. Am J Vet Res 1988, 49: I I54-II59.

21. Taylor DJ: Pig diseases 7th edition. Edited by: Bury St Edmunds. Suffolk: St Edmundsbury Press Ltd; 1999.

22. Thomson JR, Smith WJ, Murray BP: Investigations into field cases of porcine colitis with particular reference to infection with Serpulina pilosicoli. Vet $\operatorname{Rec}$ 1998, I 42:235-239.

23. Moller K, Jensen TK, Jorsal SE, Leser TD, Carstensen B: Detection of Lawsonia intracellularis, Serpulina hyodysenteriae, weakly beta-haemolytic intestinal spirochaetes, Salmonella enterica, and haemolytic Escherichia coli from swine herds with and without diarrhoea among growing pigs. Vet Microbiol 1998, 62:59-72.

24. Madec F, Bridoux N, Bounaix S, Jestin A: Measurement of digestive disorders in the piglet at weaning and related risk factors. Prev Vet Med 1998, 35:53-72.

25. Lecce JG: Dietary regimen, rotavirus, and hemolytic enteropathogenic Escherichia coli in weanling diarrhea of pigs. Ann Rech Vet 1983, 14:463-468.

26. Svensmark B, Nielsen K, Willeberg P, Jorsal SE: Epidemiological studies of piglet diarrhoea in intensively managed Danish sow herds. II. Post-weaning diarrhoea. Acta Vet Scand 1989, 30:55-62

27. Skirrow SZ, Buddle JR, Mercy AR, Madec F, Nicholls RR: Epidemiological studies of pig diseases: 2. Post-weaning diarrhoea and performance in Western Australian pigs. Aust Vet J 1997, 75:282-288.

28. Scheepens C-JM, Tielen M-JM, Hessing M-JC: Influence of daily intermittent draught on the health status of weaned pigs. Livest Prod Sci 1991, 29:24I-254.

29. Amezcua R, Friendship R, Dewey C, Gyles C: A case-control study investigating risk factors associated with postweaning Escherichia coli diarrhea in southern Ontario. J Swine Health Prod 2002, I 0:245-249.

30. Lofstedt $M$, Holmgren N, Lundeheim N: Risk factors for postweaning diarrhoea in pigs. Svensk Veterinartidning 2002, 54:457-46I.

31. Spencer BT, Howell PG: Some husbandry factors influencing weaning stresses in piglets. J $S$ Afr Vet Assoc 1989, 60:62-64.

32. Laine T, Yliaho M, Myllys V, Pohjanvirta T, Fossi M, Anttila M: The effect of antimicrobial growth promoter withdrawal on the health of weaned pigs in Finland. Prev Vet Med 2004, 66: I 63-I 74.

33. Ministry of Agriculture and Forestry. Animal diseases and animal welfare in Finland 2004. Publications 8a/2005 2005: I-29 [http://wwwb.mmm.fi/el/julk/pdf/eltaud04 en.pdf].

34. Dohoo IR, Ducrot C, Fourichon C, Donald A, Hurnik D: An overview of techniques for dealing with large numbers of independent variables in epidemiologic studies. Prev Vet Med 1997, 29:221-239.

35. McCullaugh PM, Nelder JA: Generalized linear models 2nd edition. Chapman \& Hall/CRC; 1989.

36. Venables WN, Ripley BD: Modern applied statistics with S 4th edition. Springer; 2002.

37. Ihaka R, Gentleman R: A language for data analysis and graphics. J Comput Graph Stat 1996, 5:299-314.

38. Sternberg K: Sikatarkkailun tuloksia vuodelta 2000 - niukasti dramatiikkaa. Sika 200 I, 3 I :4-7. 
39. Bark LJ, Crenshaw TD, Leibbrandt VD: The effect of meal intervals and weaning on feed intake of early weaned pigs. J Anim Sci 1986, 62:1233-1239.

40. Le Dividich J, Seve B: Effects of underfeeding during the weaning period on growth, metabolism, and hormonal adjustments in the piglet. Domest Anim Endocrinol 2000, 19:63-74.

41. Ball RO, Aherne FX: Effect of diet complexity and feed restriction on the incidence and severity of diarrhea in earlyweaned pigs. Can J Anim Sci 1982, 62:907-913.

42. Ball RO, Aherne FX: Influence of dietary nutrient density, level of feed intake and weaning age on young pigs. 2. Apparent nutrient digestibility and incidence and severity of diarrhea. Can J Anim Sci 1987, 67: I 105-III 5.

43. Rantzer D, Svendsen J, Westrom B: Effects of a strategic feed restriction on pig performance and health during the postweaning period. Acta Agric Scand Sect A, Animal Sci 1996, 46:219-226.

44. Finnish Meteorological Institute. Weather and climate 2007 [http://www.fmi.fi/weather/climate 4.html].

45. Le Dividich J, Herpin P: Effects of climatic conditions on the performance, metabolism and health status of weaned piglets: a review. Livest Prod Sci 1994, 38:79-90.

46. Le Dividich J: Effects of environmental temperature on the growth rates of early-weaned piglets. Livest Prod Sci 198I, 8:75-86.

47. Smith SH, McOrist S, Green LE: Questionnaire survey of proliferative enteropathy on British pig farms. Vet Rec 1998, | 42:690-693.

48. Glawischnig E: Contribution to weaning piglets without antibiotics. Dtsch Tierarztl Wchr 1990, 97:48-51.

49. Melin L, Wallgren P: Aspects on Feed Related Prophylactic Measures Aiming to Prevent Post Weaning Diarrhoea in Pigs. Acta Vet Scand 2002, 43:23I-245.

50. Holmgren N: Profylaktiska effekter av zinkoxid eller olaquindox mot avvänjningsdiarre hos svin (Prophylactic effects of zinc oxide or olaquindox against weaning diarrhoea in pigs). Svensk Veterinartidning 1994, 46:217-222.

5I. Kyriakis SC, Tsiloyiannis VK, Vlemmas J, Sarris K, Tsinas AC, Alexopoulos C, et al:: The effect of probiotic LSP I 22 on the control of post-weaning diarrhoea syndrome of piglets. Res Vet Sci 1999, 67:223-228.

52. Tsiloyiannis VK, Kyriakis SC, Vlemmas J, Sarris K: The effect of organic acids on the control of porcine post-weaning diarrhoea. Res Vet Sci 200I, 70:287-293.
Publish with Bio Med Central and every scientist can read your work free of charge

"BioMed Central will be the most significant development for disseminating the results of biomedical research in our lifetime. "

Sir Paul Nurse, Cancer Research UK

Your research papers will be:

- available free of charge to the entire biomedical community

- peer reviewed and published immediately upon acceptance

- cited in PubMed and archived on PubMed Central

- yours - you keep the copyright

Submit your manuscript here:

http://www.biomedcentral.com/info/publishing_adv.asp
BioMedcentral 